\title{
Germination and growth inhibitory effects of Hypericum myrianthum and $H$. polyanthemum extracts on Lactuca sativa $\mathrm{L}$.
}

\author{
Daniela Fritz, ${ }^{1}$ Ana Paula Bernardi ${ }^{1}$, Juliana S. Haas ${ }^{1}$, Bruna M. Ascoli ${ }^{1}$, Sérgio Augusto de \\ Loreto Bordignon ${ }^{2}$, Gilsane von Poser ${ }^{1 *}$
}

\author{
${ }^{1}$ Programa de Pós Graduação em Ciências Farmacêuticas, Universidade Federal do Rio Grande do Sul, Av. \\ Ipiranga, 2752, 90610-000, Porto Alegre, RS, Brazil, \\ ${ }^{2}$ Curso de Ciências Biológicas, Universidade Luterana do Brasil, Avenida Itacolomi, 3600,
}

94170-240, Gravatai, RS, Brazil

\begin{abstract}
RESUMO: "Efeito inibitório de extratos de Hypericum myrianthum e H. polyanthemum sobre a germinação e crescimento de Lactuca sativa $\mathbf{L}$ ". Neste trabalho foi investigado o efeito inibitório de extratos etanólicos de partes aéreas de Hypericum myrianthum e Hypericum polyanthemum sobre a germinação e o crescimento de alface (Lactuca sativa). A germinação das sementes foi reduzida em todas as concentrações avaliadas. Após sete dias, o percentual de germinação foi significativamente retardado pelos extratos de ambas as plantas, nas maiores concentrações, em comparação com o grupo controle. O comprimento das radículas foi significativamente afetado, estas apresentando alguns sinais de necrose. As duas espécies apresentam compostos fenólicos como constituintes principais, os quais podem ser responsáveis pela inibição da germinação e crescimento de Lactuca sativa.
\end{abstract}

Unitermos: Hypericum myrianthum, Hypericum polyanthemum, Lactuca sativa, atividade alelopática, radícula, germinação de sementes.

\begin{abstract}
Germination and growth inhibitory effects of ethanolic crude extracts of Hypericum myrianthum and $H$. polyanthemum aerial parts on lettuce (Lactuca sativa) were investigated. The germination was retarded in all the tested concentrations. After seven days the final germination percentage of the most concentrated extracts was significantly reduced by both extracts in comparison with the control. The radicles length was significantly affected showing necrosis. Both species present phenolic compounds as the main components and they could be responsible for the inhibition of the germination and growth of Lactuca sativa.
\end{abstract}

Keywords: Hypericum myrianthum, Hypericum polyanthemum, Lactuca sativa, allelopathic effects, radicle length, seed germination.

\section{INTRODUCTION}

Germination and growth inhibitory effects of plant metabolites are frequently associated to allelopathy. This process plays an important role in both natural and agro-ecosystems and should be defined as any stimulatory or inhibitory effect by one plant on another through production of chemical compounds released into the environment (Rice, 1984, Oliveira et al., 2004). Suitable manipulation of the allelopathy towards improvement of crop productivity and environmental protection through eco-friendly control of weeds, pests, crop diseases, conservation of nitrogen in crop land and synthesis of novel agrochemicals based on natural products have gained prominent attention of scientists.

A variety of secondary plant metabolites are released into the soil, either as exudates from living plant tissues or by decomposition of plant residues (Rice, 1984, Rizvi; Rizvi, 1992). Some of these substances may be associated with allelopathy, and play an important role in chemical interactions in natural plant communities (Einhelling, 1996, Seigler, 1996, Dayan et al., 2000). In fact, a number of plants have been reported to possess inhibitory effects on the growth and population of neighboring or succession plants by releasing allelopathic substances into the soil (Rice, 1984, Inderjit, 1996, Narwal, 1999).

In Southern Brazil, 20 Hypericum species are found (Robson, 1990). Some species are widely distributed all over the state of Rio Grande do Sul, but they never form dense population. Nevertheless some species show another pattern of distribution: H. polyanthemum is somewhat restrict to delimited regions but not dominant and others, as H. myrianthum, are also restrict but appear as dense population. Considering the distribution of these plants we decided to investigate the allelopathic potential of $H$. polyanthemum and $H$. myrianthum in order to know some aspects about their physiology, especially the 
former which is a plant menaced of extinction.

\section{MATERIAL AND METHODS}

\section{Plant material}

H. myrianthum Cham. \& Schlecht. and $H$. polyanthemum Klotzsch ex Reichardt aerial parts were collected in Paraíso do Sul and Caçapava do Sul, respectively, in November 2005. Voucher specimens were deposited in the herbarium from Universidade Federal do Rio Grande do Sul (ICN) (Bordignon 1402, Bordignon et al. 1409).

\section{Preparation of plant extracts}

Twenty grams of the dried and powdered plant material (aerial parts) were extracted with ethanol by maceration $(3 \times 24 h)$, yielding total ethanol crude extracts that were evaporated to dryness under reduced pressure at $45{ }^{\circ} \mathrm{C}$ in order to obtain a final volume of $20 \mathrm{~mL}$. For the test these extracts were diluted obtaining the following concentrations: $1: 1,1: 2,1: 4,1: 8,1: 16,1: 32,1: 64$ e 1:128 (mass:volume)(in ethanol).

\section{Germination and growth inhibitory assay}

Two milliliters of each test sample were added to a sheet of filter paper (No. 1) in a $6 \mathrm{~cm}$ Petri dish and dried. Then, $2 \mathrm{~mL}$ of distilled water were distributed to each Petri dish and 50 seeds of lettuce (Lactuca sativa L.) were arranged on the filter paper. Control seedlings were treated only with distilled water. The experiments were carried out under natural light and at room temperature. The number of germinated seeds was counted (rupture of seed coat and emergence of radicle) each day for 7 days after which no further seed germination occurred. The length of the radicles was measured at the end of the experiment and the percentage elongation of the roots was determined by reference to the elongation of control roots.

All the experiments were conducted in triplicate and the control seedlings were only treated with distilled water. The seed treatments were prepared using sterile disposable Petri dishes, sterile water and filter paper. The seeds were maintained under aerobic conditions and no attempt was made to maintain dishes under antiseptic conditions.

\section{Statistical analysis}

Differences in the percentages of seed germination and root growth were assessed by Tukey Test. The difference between the extracts of the two species was accessed by ANOVA test. Values of $p<0.05$ were regarded as significant.

\section{Total phenolic content}

Total phenol concentration in the crude ethanolic extracts was determined spectrophotometrically according to the Folin-Ciocalteu colorimetric method with a little modification (Singleton; Rossi, 1965), using quercetin as standard. Briefly, the appropriate dilutions of the samples were oxidized with $0.2 \mathrm{~N}$ Folin-Ciocalteu reagent $(2 \mathrm{~N}$, diluted ten-fold) and after $5 \mathrm{~min}$ the reaction was neutralized with saturated sodium carbonate (10.6 $\%)$. The absorbance of the resulting blue color was measured at $765 \mathrm{~nm}$ with an ultraviolet-visible Hewlett Packard 8451A spectrophotometer after incubation for $30 \mathrm{~min}$ in the dark at room temperature. Quantification was done on the basis of the standard curve of quercetin

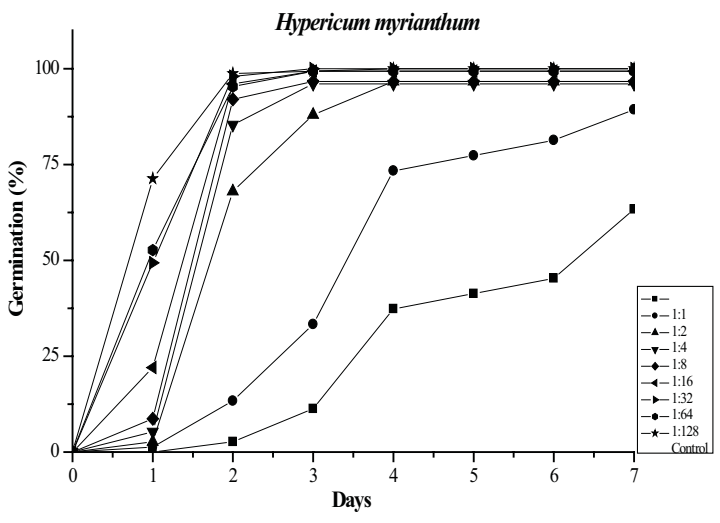

(a)

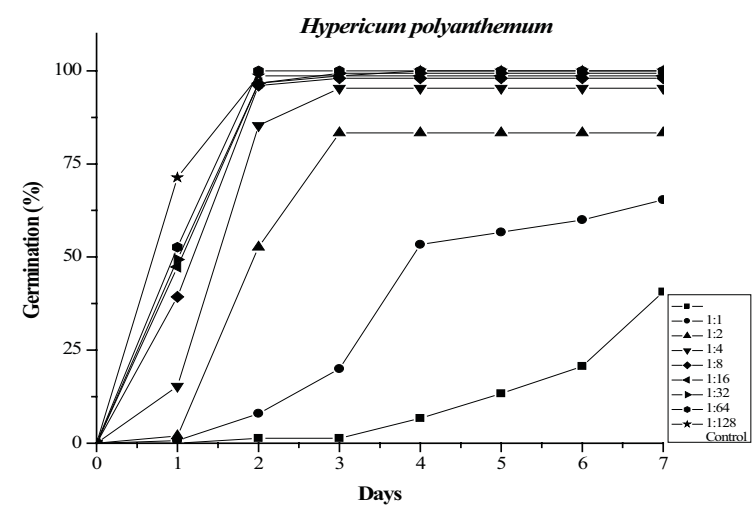

(b)

Figure 1. Effect of ethanolic extract of H. myrianthum (a) and H. polyanthemum (b) on the lettuce seed germination 
(Ivanova et al., 2005), and the results were expressed as quercetin equivalent $(\mathrm{QE})$ (milligrams of quercetin per gram of plant dry extract) calculated by the following equation: $\mathbf{C}=\mathbf{c V} / \mathbf{m}$, where $\mathbf{C}$ is the total content of phenolic compounds ( $\mathrm{mg} / \mathrm{g}$ plant dry extract, in $\mathrm{QE})$, c is the concentration of quercetin established from the calibration curve $(\mathrm{mg} / \mathrm{mL}), \mathbf{V}$ is the volume of plant extract $(\mathrm{mL})$ and $\mathbf{m}$ is the weight of plant extract used at measurement (g) (Miliauskas et al., 2004).

\section{RESULTS AND DISCUSSION}

Lettuce seeds (Lactuca sativa), the common allelopathy bioassay system, were germinated in the presence of different concentrations of the ethanolic extracts from the aerial parts of $H$. myrianthum and $H$. polyanthemum. In the germination and growth inhibitory assays, percentage of seed germination, root elongation and hypocotyl/epicotyl growth were affected by ethanolic extracts. The percentage of seed germination is shown in figure 1 ( $a$ and $b)$.

In the experiments the radicle protrusion was taken as parameter. It was observed that the extracts, in all the tested concentrations affected the lettuce radicles; even in the highest dilution (1:128) the tip of the radicles showed some necrosis. In dilutions lower than 1:16 the radicles became shorter and died. The alcoholic extracts of both plants retarded the germination of the lettuce seeds in all the concentrations tested $(p<0.05)$. After seven days the final germination percentage of the most concentrated extracts was significantly reduced by both extracts in comparison with the control. Significant differences among the dilutions $1: 16,1: 8,1: 2$ and 1:1 were found. The extracts of both plants displayed a similar inhibitory action. The radicle development was observed every day by visual inspection, but the length was measured only at the end of the experiment. The results are shown in figure 2 ( $a$ and $b$ ).

Elongation of lettuce radicles was visibly affected by both plant extracts after 48 hours in the lettuce seed experiments. After 7 days, the radicles were significantly $(p<0.05)$ shorter in dilutions lower than 1:16. Radicles of seedlings treated with the extracts were brown in color compared with the white radicles of the control seedlings.

During the experiment the hypocotyl/epicotyl development was observed. Although the length was not measured the effect of the extracts was visible. In dilutions between 1:128 and 1:64 the growth was similar to the control but in dilutions lower than 1:64 the growth was retarded and the seedling plants were shorter and presented deformity comparing to the control. Dilutions lower than 1:32 inhibited the hypocotyl development. All of these results could suggest that the ethanolic extracts of Hypericum myrianthum and $H$. polyanthemum exhibited allelopathic effects.

It is well known that several plants produce allelopathic compounds. The phenomenon of allelophathy encompass all types of chemical interactions among plants and could account for the observation that certain plants sometimes do not grow in places where other plants occur. Moreover, it was shown that extracts of some plants inhibit the growth of others (Dias et al., 2005). With regard to allelopathic effects of plant secondary metabolites, it is now generally recognized that some terpenoids, mainly monoterpenes and sesquiterpenes present in the volatile fractions (Fischer, 1991, von Poser et al., 1996) and phenolic compounds are the principal responsible for growth inhibition of competing plants (Harborne, 1993).

\section{Hypericum myrianthum}

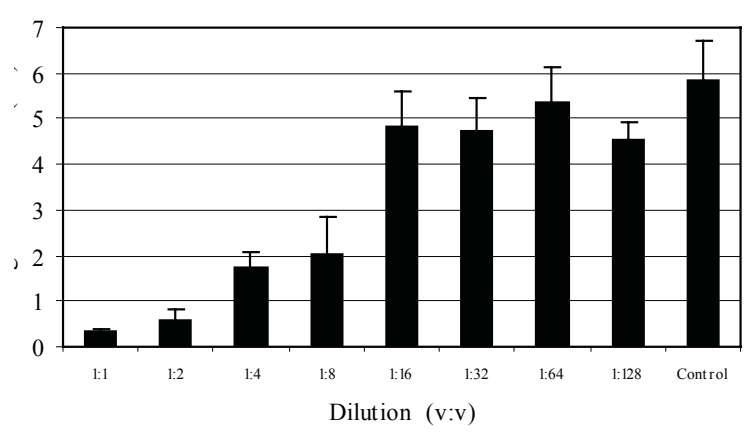

(a)

\section{Hypericum polyanthemum}

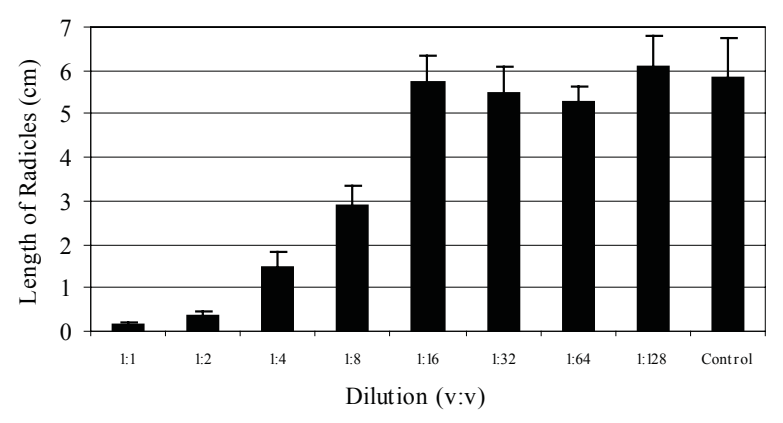

(b)

Figure 2. Effect of ethanolic extract of H. myrianthum (a) and H. polyanthemum (b) on the lettuce radicle length after 7 days. 
The essential oil content of the aerial parts of both plants was previously obtained by hydrodistillation applying Clevenger apparatus. Hypericum myrianthum and $H$. polyanthemum presented 0.5 and $0.2 \%$ of essential oil, respectively (Ferraz et al., 2005). Essential oils are recognized allelopathic compounds and even in low concentration they may influence the growth inhibition of competing plants. Nevertheless Hypericum species have a strong tendency in accumulating phenolic compounds (Bara et al., 2006) and the detected activity is probably due to this class of allelochemicals.

Phenolic compounds play a major role in the interaction of plants with their environment. They may attract insects, function as signals between plants and symbiotic or pathogenic organisms and may protect plants against biotic or abiotic stresses. Besides that, phenolics represent the main allelopathic compounds that inhibit seed germination, plant growth and other physiological processes which result in changes of floristic composition within a plant community and dominance of one plant species over others (Harborne, 1993, Djurdjević et al., 2005).

Polyphenol compounds such as tannins, flavonoids and phenolic acids were the most prominent components of the crude extracts investigated and could contribute to the germination and growth inhibitory activity of the Hypericum species extracts (Dall'Agnol et al., 2003). The total phenolic compounds were quantified in the ethanolic extracts of the aerial parts of the plants using a colorimetric oxidation/reduction reaction with the Folin-Ciocalteu reagent. Both plants presented high amounts of total phenolic compounds expressed as quercetin equivalent $(\mathrm{QE}): 120.6 \pm 1.1$ and $121.4 \pm$ $4.7 \mathrm{mg} / \mathrm{g}$ of dry extract for $H$. polyanthemum and $H$. myrianthum respectively.

The tannin content of the surveyed plants was determined as described by Dall'Agnol et al. (2003), using the hide power method; Hypericum polyanthemum and $H$. myrianthum gave tannins in $6.7 \%$ and $5.1 \%$ yields, respectively. This group of substances is usually found in Hypericum species in amounts that can reach $17 \%$ (Dall'Agnol et al., 2003). It is known that tannins form irreversible complexes with proteins (Hagerman; Butler, 1981), which would result in the inhibition of enzymatic systems. This property could explain the mechanisms of action of the plant extracts. Reports of several in vitro assays demonstrate potentially significant interactions with biological systems, such as virus, bacteria, and mollusk. Tannins also show enzyme inhibiting, antioxidant, and radical-scavenging properties (De Bruyne et al., 1999) and they possibly interfere with the growth of nitrifying bacteria (Lodhi; Killingbeck, 1980) and inactivate plant $\beta$-glucosidases (Spencer, 1988), which may cause inhibition in the plants germination and growth.

Another phenolic compounds that have shown allelopathic activity are the flavonoids. These compounds are widely distributed in bryophytes and vascular plants, and ca. 5,000 kinds have been reported as naturally occurring substances. Many biological activities of the flavonoids including pollinator attractants, oviposition stimulants, feeding attractants and deterrents, phytoalexins and allelopathy have been found. Several flavonoids such as quercetin, isoquercitrin, rutin, and quercetrin among many others have shown effects on plant growth (Rivera-Vargas et al., 1993, Parvez et al., 2004, Iqbal et al., 2005).

Among the flavonoids present in these Hypericum species, hyperoside (quercetin-3-Ogalactopyranoside) is the most abundant and this compound along with quercitrin and isoquercitrin, also present in the plants (Dall'Agnol et al., 2003) could be involved in the germination and growth inhibitory effects determined in this work. This flavonoid was previously isolated from the ethanolic extract of Juglans regia L. leaves with potential allelopathy and demonstrated remarkable effects on the growth of lettuce seedlings and inhibitory activity against tobacco mosaic virus (TMV) (Gao; Zhang, 2004).

Allelopathy may have two functions in a plant: phytotoxic and autotoxic. Within the range of its capability to overcome stress, allelopathy is inhibitory to others except to the producer. Under severe stress, which is beyond the adjusting capability of the plant, such as massive attack by pathogens or severe mineral deficiencies, allelopathy may act autotoxically to decrease the population of the producer, which may be the best survival strategy for producer plants under unfavorable conditions (Chou, 1989, Hegazy et al., 1990). It has been observed that residues from plants grown under stressful conditions are more highly phytotoxic than under normal conditions (Mason-Sedun; Jessop, 1989).

Taking into account that both plants displayed similar activity affecting seed germination, root elongation and hypocotyl/epicotyl development and both have a similar chemical composition it seems reasonable to assume that in the case of $H$. polyanthemum the compounds are autotoxic. This activity could justify the occurrence of a reduced number of individuals in places where the species grows naturally, a somewhat arid and rocky field where the soil, not deep, is a conglomerate formed by rocks of sedimentary origin.

The germination and growth inhibitory effects of the extracts of $H$. myrianthum and $H$. polyanthemum on Lactuca sativa could be related to the high amount of phenolic compounds present in these plants. Nevertheless, these results do not necessarily mean that the extracts have allelopathic effects; they could be due to phytotoxic effect of the Hypericum extracts. Some additional experiments should be performed with seeds of other plants e.g. mustard which is much more resistant. Moreover, germination test of $H$. polyanthemum in its own extract would determine the autotoxicity of this plant. 


\section{ACKNOWLEDGEMENTS}

The authors thank Simone Cargnin and Raquel Fenner for the technical assistance, and CNPq, CAPES and Propesq for the financial support.

\section{REFERENCES}

Bara MTF, Ribeiro PAM, Arantes MCB, Amorim LLSS, Paula JR 2006. Determinação do teor de princípios ativos em matérias-primas vegetais. Rev Bras Farmacogn 16: 211-215.

Chou CH 1989. The role of allelopathy in phytochemical ecology. In: Chou CH, Waller GR (ed.) Phytochemical ecology: Allelochemicals, mycotoxins and insect pheromones and allomones. Taipei: Institute of Botany, Academia Sinica, p.19-38.

Dall'Agnol R, Ferraz A, Bernardi AP, Albring D, Nor C, Sarmento L, Lamb L, Hass M, von Poser GL, Schapoval EES 2003. Antimicrobial activity of some Hypericum species. Phytomedicine 10: 141-147.

Dayan FE, Romagni JG, Duke SO 2000. Investigating the mode of action of natural phytotoxins. $J$ Chem Ecol 26: 2079-2094.

De Bruyne T, Pieters L, Deelstra H, Vlietinck A 1999. Condensed vegetable tannins: Biodiversity in structure and biological activities. Biochem Syst Ecol 27: 445-449.

Dias JFG, Círio GM, Miguel MD, Miguel OG 2005. Contribuição ao estudo alelopático de Maytenus ilicifolia Mart. ex Reiss., Celastraceae. Rev Bras Farmacogn 15: 220223.

Djurdjević L, Mitrović M, Dinić A, Pavlović P, Bojović S, Gajić G, Kostić O 2005. Allelopathic investigations of Quercus conferta and Quercus cerris domination in oak forest at Avala Mt. (Serbia). Fourth World Congress of Allelopathy. Wagga Wagga, Australia.

Einhellig FA 1996. Interactions involving allelopathy in cropping systems. Agron J 88: 886-893.

Ferraz ABF, Limberger RP, Bordignon S, von Poser GL, Henriques AT 2005. Essential oil composition of six Hypericum species from Southern Brazil. Flav Frag J 20: 335-339.

Fischer NH 1991. Plant terpenoids as allelopathic agents. In: Harborne JB, Tomas-Barberan FA (ed.) Ecological chemistry and biochemistry of plant terpenoids. Oxford: Clarendon Press, p.377-398.

Gao JM, Zhang AL 2004. Bioactive constituents from Juglans regia. Symposium "Plants in Health and Culture". Leiden, The Nederlands.

Hagerman AE, Butler LG 1981. The specificity of proanthocyanidin-protein interactions. $\mathrm{J}$ Biol Chem 256: 4494-4497.

Harborne J 1993. Introduction to ecological biochemistry. London:Academic Press.

Hegazy AK, Mansour KS, Abdel-Hady NF 1990. Allelopathic and autotoxic effects of Anastatica hierochuntica L. $J$ Chem Ecol 16: 2183-2193.

Inderjit 1996. Plant phenolics in allelopathy. Bot Rev 62: 186202.

Iqbal Z, Golisz A, Furubayashi A, Nasir H, Fujii Y 2005. Allelopathic potential of buckwheat. Fourth World Congress of Allelopathy. Wagga Wagga, Australia.
Ivanova D, Gerova D, Chervenkov T, Yankova T 2005. Polyphenols and antioxidant capacity of Bulgarian medicinal plants. J Ethnopharmacol 96: 145-150.

Lodhi MAK, Killingbeck KT 1980. Allelopathic inhibition of nitrification and nitrifying bacteria in a ponderosa pine (Pinus ponderosa Dougl.) community. Am J Bot 67: 1423-1429.

Mason-Sedun W, Jessop RS 1989. Differential phytotoxicity among species and cultivars of the genus Brassica to wheat. III. Effects of environmental factors during growth on the phytotoxicity of residue extracts. Plant Soil 117: 93-101.

Miliauskas G, Venskutonis PR, van Beek TA 2004. Screening of radical scavenging activity of some medicinal and aromatic plant extracts. Food Chem 85: 231-237.

Narwal SS 1999. Allelopathy update. Basic and applied aspects. Enfield, New Hampshire: Science Publishers.

Oliveira SCC, Ferreira AG, Borghetti F 2004. Efeito alelopático de folhas de Solanum lycocarpum A. St.Hil. (Solanaceae) na germinação e crescimento de Sesamum indicum L. (Pedaliaceae) sob diferentes temperaturas. Acta Bot Bras 18: 401-406.

Parvez MM, Tomita-Yokotani K, Fujii Y, Konishi T, Iwashina T 2004. Effects of quercetin and its seven derivatives on the growth of Arabidopsis thaliana and Neurospora crassa. Biochem Syst Ecol 32: 631-635.

Rice EL 1984. Allelopathy. New York: Academic Press.

Rivera-Vargas LI, Schmitthenner AF, Graham TL 1993. Soybean flavonoid effects on and metabolism by Phytophthora sojae. Phytochemistry 32: 851-857.

Rizvi SJ, Rizvi V 1992. Allelopathy basic and applied aspects. London: Chapman \& Hall.

Robson NKB 1990. Studies in the genus Hypericum L. (Guttiferae) 8. Sections 29. Brathys (part 2) and 30. Trigynobrathys. Bull Brit Mus (Nat. Hist) 20: 1-151.

Seigler DS 1996. Chemistry and mechanisms of allelopathic interactions. Agron J 88: 876-885.

Singleton VL, Rossi, JA 1965. Colorimetry of total phenolics with phospho-molybdic-phosphotungstic acid reagents. Am J Enol Viticult 16: 144-158.

Spencer CM, Cai Y, Martin R, Gaffney SH, Goulding PN, Magnolato D, Lilley TH, Haslam E 1988. Polyphenol complexation-some thoughts and observations. Phytochemistry 27: 2397-2409.

von Poser GL, Menut C, Toffoli ME, Verin P, Sobral M, Bessiere JM, Lamaty G, Henriques, AT 1996. Essential oil composition and allelopathic effect of the Brazilian Lamiaceae Hesperozygis ringens (Benth.) Epling and Hesperozygis rhododon Epling. J Agric Food Chem 44: 1829-1832. 